\title{
KERRON HÄNEN ISÄLLENSÄ
}

\section{Toisin luettuja miesten välisiä suhteita suomalaisessa kevyessä musiikissa}

\section{Harto Hänninen}

Populaarimusiikin kuvasto on usein kliseistä ja sen tarjoamat roolimallit konservatiivisia ja ennalta-arvattavia. Laulujen sanoituksia on kuitenkin mahdollista tarkastella myös toisin. Niitä voidaan lukea mediaesityksinä, joiden sisältöjen voi jopa tulkita kyseenalaistavan valtaväestön normeja. Jos lauluteksti on kirjoitettu viattomasti tiettyä sukupuolta edustavan henkilön laulettavaksi, mutta esittäjä edustaakin eri sukupuolta, koko sisältö ikään kuin nyrjähtää särölle ja altistuu uudenlaiselle tulkinnalle. Iskelmän representaatio ei äkkiä tuekaan turvalliseksi koettua heteronormatiivista maailmankuvaa, vaan avaa yllättävän näkökulman homoseksuaalisiin suhteisiin. (Vrt. Karkulehto 2011, 36; 42-45; 51.)

Tässä esseessä tarkastelen kuutta laulua toista maailman sotaa edeltävältä ajalta ja kahta 1950- ja 1960-luvulta. Laulut ovat valikoituneet omien kuunteluharrastusteni mukaisesti: olen harrastanut kotimaisten 1910-1960-lukujen kuplettien ja jatsahtavien iskelmien kuuntelua yli kolmekymmentä vuotta. Toisinaan laulujen sanoitukset jäävät askarruttamaan mieltä joko nokkeluudellaan, outoudellaan tai tahattomalla koomisuudellaan. Monesti huomaan pysähtyväni miettimään laulajan suhdetta esitettyyn laulutekstiin. Kun laulun sisältö ja esittäjä ovat selvästi ”eriparisia”, alkaa laulun tarina kutkuttaa mielikuvitusta. Aineiston paljoudesta olen huoli- nut mukaan vain mieslaulajien esittämiä lauluja, joissa käy selkeästi ilmi, että lauletaan saman sukupuolen edustajalle tai edustajasta romanttisesti. Kun sanoituksesta ei ole mainittu painettua lähdettä, sitaatit perustuvat korvakuulolta poimittuihin sanoihin.

Katson lauluja queer-teorioiden näkökulmasta ja pyrin erittelemään, miten niistä voi lukea ilmauksia sellaisista seksuaalisuuksista ja identiteeteistä, jotka eivät palaudu heteronormatiiviseen parisuhteeseen (Karkulehto 2011, 73-74). Etsin queer-tutkimuksen metodein säröjä, joiden kautta voi kyseenalaistaa vanhojen laulujen hetero-oletuksen, jota valtakulttuuriin kuuluva viihdeteollisuus pyrkii koko ajan ylläpitämään ja normalisoimaan. Annan laulujen sisällön kyseenalaistaa laulun kertojan seksuaali-identiteetin. (Karkulehto 2011, 86; Rossi 2003, 12-13.) Lähestyn laulutekstejä mediarepresentaatioina, joiden sisältö muuttuu, kun niitä tarkastellaan oletusarvon vastaisesti. Karkulehto (2011, 55-57) esittelee Judith Fetterleyn alunperin lanseeraaman käsitteen "vastustava lukeminen" tai "vastakarvaan lukeminen". Toisin lukeminen tarjoaa mahdollisuuden löytää myös marginalisoiduille ryhmille mielekkäitä tulkintoja valtavirralle suunnatuista teoksista. Esittämäni tulkinnat saattavat joidenkin mielestä näyttää irvailevilta ja vierailta, sillä enemmistöllä ei ole tarvetta vastustaa 
mediaesitysten perinteistä, heteronormatiivista luentaa. Tarkoitukseni ei ole esittää, että ehdottamani tulkinnat olisivat olleet omana aikanaan tietoisesti rakennettuja rinnakkaistarinoita; nämä tulkinnat edellyttävät queer-tietoista katsetta nykyajasta menneisyyteen. Omalla tavallani haluan tarjota väylän, jossa toisenlainen narratiivi pystyy neuvottelemaan oikeudestaan olemassaoloon myös historiassa ja nostalgiassa. Kirjallisuudessa haasteeksi on usein osoittautunut yhteiskunnan asettamien kankeiden roolimallien ja odotusten läsnäolo, joka edellyttää vastakarvaanlukijalta sinnikästä ja tietoista näkökulman valintaa (vrt. Fetterley 1978, ixx-xx). Valitsemieni iskelmien kohdalla laulajien sukupuoli helpottaa vaihtoehtoisen näkökulman hahmottamista ja ylläpitämistä.

Vanhimmat esimerkkikappaleet ovat Iivari Kainulaisen levyttämät kansansävelmät "Hampurin heila" ja "Aittalaulu" vuodelta 1912. Hupilaulaja ja kupletisti Kainulainen kuuluu Alfred J. Tannerin kanssa niihin harvoihin suomeksi laulaneisiin viihdetaitajiin, jotka levyttivät jo 1910-luvun alussa (Gronow \& Saunio 1990, 80). Tatu Pekkarisen sanoittama "Helsingin heila muistelee livanaa" on vuodelta 1928. "Savolainen sanaseppo" Pekkarinen tuotti paljon laulutekstiä niin kupletteihin kuin tanssi-iskelmiinkin (Hirviseppä 1969, 99-103). Pekkarisen oma levytys laulusta on kuplettimainen kertomus, mutta pari vuotta myöhemmin sen levytti Theodor Weissman, ja silloin laulusta tuli kipakka jenkka. ”Tettu” Weissmanin vuonna 1930 levyttämän version nimi on "Iivanan jenkka", ja levytyksessä on merkittävä tekstimuutos, joka on kääntänyt koko laulun perspektiivin.

Vanhemmista valitsemistani lauluista tunnetuin on Reino Palmrothin sanoittama "Sörkän ruusu", joka kuultiin ensi kerran levyllä Ilmari Sitarin esittämänä vuonna 1932. Palmroth oli varhaisen Suomi-iskelmän ahkerimpia sanoittajia, joka laati vuosina 1929-1932 yli 50 laulutekstiä. Pitkän uransa aikana hän käytti myös nimimerkkejä Palle, Reino Hirviseppä sekä M. Turma. (Bagh \& Hakasalo 1986, 176-179; Hirviseppä 1969, 165-168;
Kukkonen 1980, 69.) Toisen maailmansodan jälkeisestä nuorisomusiikista olen valinnut kaksi laulua, jotka molemmat sattuvat olemaan versioita Brita Koivusen listahiteistä. "Suklaasydämen" on sanoittanut Saukki eli Sauvo Puhtila, joka oli tunnettu nimenomaan ulkomaisten käännösiskelmien sanoittajana (Bagh \& Hakasalo 1986, 357-358). Brita Koivusen suurhitti "Suklaasydän" tallentui samana vuonna (1956) levylle myös Reijo Kallion laulamana samoilla sanoilla. Kari Tuomisaaren sanoittaman letkeän "Mustapha"-hitin levyttivät Raittisen veljekset Eero ja Jussi vuonna 1960, jolloin Koivunenkin sen levytti. Teksti on molemmissa versioissa sama.

\section{Nätti poika Hampurissa ja laulajapoika naapurissa}

Iivari Kainulaisen levyttämät "Hampurin heila" ja "Aittalaulu" vuodelta 1912 edustavat suomenkielisen äänilevytuotannon varhaisinta kerrostumaa. Useimmat ennen vuotta 1915 tuotetut äänilevyt olivat klassista musiikkia tai torvisoittolevyjä, ja suomalaistenkin esiintyjien levyt käytiin äänittämässä ulkomailla. Sanoitetusta viihdemusiikista vastasivat lähinnä humoristiset kuplettilaulajat J. Alfred Tanner ja Iivari Kainulainen, jotka levyttivät runsaasti laulettua musiikkia, ennen kuin maailmansota halvaannutti eurooppalaisen levytuotannon vuosiksi 1915-1925. (Gronow \& Saunio 1990, 79-81.) Molempien laulujen sanoituksesta käy ilmi, että ne on tarkoitettu naispuolisen kertojan suuhun. Suomessa ei kuitenkaan ollut kevyttä musiikkia levyttäviä naislaulajia ennen ensimmäistä maailmansotaa; naisäänistä levylle tallentuivat lähinnä Aino Actén ja Ida Ekmanin kaltaiset oopperatähdet (Gronow \& Saunio, 1990, 78).

Vaikka näiden varhaisten laulujen tahallinen väärinymmärtäminen, "vastakarvaan lukeminen", on melkoisen viatonta ja ilmeistä, täytyy muistaa, että laulujen levytysaikana mediarepresentaatioiden, varsinkin kevyen musiikin, hetero-oletus oli lähes sataprosenttinen: toisenlaiselle halulle 
ei ollut käytännössä minkäänlaista positiivista samastumiskohdetta (vrt. Karkulehto 2011, 80). Ennen ensimmäistä maailmansotaa mediassa ei juurikaan tunnettu sanaa homoseksuaalisuus, eikä samansukupuolisista suhteista voitu kirjoittaa, sillä homoseksuaaliset teot olivat laittomia (Hagman 2016, 64-68). Iivari Kainulainen laulaa suoraan haluttavista pojista, ja laulutavan sydämenpohjasta kumpuavan tunteen ansiosta lauluihin on asettunut kutkuttava homoeroottinen lataus. "Hampurin heilan" sanoitus on yksinkertainen ja toiveikas:

Mull' on heila Hampurissa

juu juu ja joo joo

se on sievä, nätti poika

soosoo ja ohhoo

Heilani kun minut näkkee

juu juu ja joo joo

luulee olevan herrasväkkee

soosoo ja ohhoo

Heilani kun minut ottaa

juu juu ja joo joo

sormuksen hän mulle antaa

soosoo ja ohhoo

Laulun queer-tulkinta on hyvin nykyaikainen, sillä sata vuotta laulun ilmestymisen jälkeen ulkomaisessa gayheilassa ei ole mitään yllättävää (varsinkaan jos Hampurin korvaa Berliinillä). Tässä kertojan ja hänen "sievän ja nätin" poikaheilansa kohtaamiseen liittyy myös pukufetissi; kertoja haluaa antaa herraskaisen vaikutelman, vaikka lausemuoto ja puhekielinen ilmaisu paljastavat, että hän saattaa olla peräti työväenluokkainen sälli. Samansukupuolisten välistä intohimoa pidettiin usein herrasväen yläluokkaisena paheena, joka muuttui työväen parissa vulgaariksi (Hagman
2016, 72). Laulun viimeinen säkeistö muuttuu Kainulaisen tulkinnassa suoran eroottiseksi. Säettä "Heilani kun minut ottaa" seuraava "juu juu ja joo joo" venyy laulajan suussa sen verran, että ottamisen laadusta ja intensiivisyydestä ei jää kuulijalle epäselvyyttä.

Laulun ainoa hetki, joka lyö pienen särön gaytarinan eheyteen, on viimeisen säeparin toisto, jonka Kainulainen laulaa muodossa "sormuksen hän mulle antaa / joo joo ja ohhohhoijaijaa". Viimeinen "ohhohhoijaijaa" lähtee falsetissa ja laskeutuu pitkästyneesti: falsettilaulu tai -puhe oli kuplettien yleinen tapa imitoida groteskin koomisesti naista (Henriksson 2014, 90). Kovin vakuuttavasti Kainulainen ei kuitenkaan naiseksi tekeydy, ja kiekaisusta tulee mieleen pikemminkin parodinen homoassosiaatio liioittelevine ranneliikkeineen. Ikään kuin laulaja olisi hyvin tietoinen siitä, että ulkomaan heila on vain ohimenevä hurmio, eikä tarjottu sormuskaan tarkoita sen vakavampaa.

Kainulaisen toinen poikarakkautta julistava laulu on kirjailija Larin-Kyöstin sanoittama "Aittalaulu". Se muistuttaa tyyliltään kansanlaulua.

Tule, tule naapurin laulajapoika

täällä mä yksin jo ikävän̈ni itkin.

Luokseni joudu, mut hiljaa.

Kule, kule hiipien peltoja pitkin,

vaan älä tallaa viljaa.

Laulun tarinassa on kaikki salasuhteen pakolliset elementit: kylän eukot vaanivat, täytyy tapailla salaa iltayöstä, mieleen hiipii epäilys. Kuvastosta piirtyy agraarinen yhteiskunta, jossa laulajan ja naapurin pojan suhde on mitä ilmeisin poikkeama heteronormatiivisesta ympäristöstä.Jan Löfströ$\min (1999,196-199$; 2015, 132-135) mukaan homoseksuaalisuus maaseudulla ei ollut vaikenemalla salattua tai torjuttua; se peittyi hiljaisuuteen, koska seksuaalisuutta ei pidetty yhtä olennaisena arvostuksen ja aseman 
mittarina kuin esimerkiksi työsuoritusta. Se ei suinkaan tarkoita, että homoseksuaalinen halu tai käytös olisi ollut hyväksyttyä tai tasa-arvoista, vaan Löfström toteaa sen kyllä joutuneen naurun ja selittelyn kohteeksi. Asian vähäpätöisyyttä todistanee kuitenkin se, että miesten homoseksuaalista käytöstä kuvaavia kaskuja on tallennettu agraariyhteisöistä toista maailmansotaa edeltävältä ajalta erittäin marginaalisesti, vaikka miehuutta ja seksuaalista kyvykkyyttä kuvaavia sanontoja riittää (Löfström 1999, 44-47; 134-139). Mielestäni "Aittalaulusta" kuvastuu herkästi se "rakkaus, joka ei tohdi lausua nimeään"; tässä tapauksessa ei välttämättä edes tiedä nimeään. Salattu, nimeämätön lempi määrittää koko ihmissuhteen olemisen rajat ja tavat, joilla siitä voi puhua (Sedgwick 1990, 68-69).

Salassa pidettävän suhteen epävarmuus on riipaiseva:

Tule, tule taasen ja laula niin kuin ennen

jotta sais sydänsuru vaimennusta.

Vai joko aattelet toista?

Älä, älä hylkää, nyt yökin on musta.

Voi tule, huoleni poista!

Siihen nähden, kuinka selkeästi tytön suuhun kuuluvaksi Larin-Kyösti on kauniin tekstinsä kirjoittanut, on perin erikoista, että laulun ovat levyttäneet vain mieslaulajat.

\section{Unohtumatonta puistoseksiä}

Tatu Pekkarisen laajassa tuotannossa on pilkkakupletti "Helsingin heila kaipaa Iivania", joka mitä ilmeisimmin sijoittuu vuoteen 1918, jolloin Venäjän keisarillisen armeijan joukot kotiutettiin itsenäistyneestä Suomesta. Pekkarinen levytti venäläiseen kansansävelmään pohjautuvan laulelmansa vuonna 1928. Pari vuotta myöhemmin laulusta tehtiin toinen levytys, jonka esittivät Theodor Weissman ja Homocord-orkesteri. Tämä vuoden 1930 versio sai nimekseen "Iivanan jenkka", ja ero alkuperäiseen on merkittävä niin esityksenä kuin tekstinäkin. Siinä missä Tatu Pekkarisen oma versio on lähes läpilaulettu moraalinen tarinankerronta vailla tunnetta ja kohokohtia, on Weissmanin ja Homocord-orkesterin esitys täynnä lihaa, tunnetta ja sävyjä, ja kupletin rytmi on muuttunut raskaalla poljennolla eteneväksi jenkaksi, josta puuttuu kuitenkin tanssin kepeys.

Laulun alussa kertoja on itkussa suin muistelemassa armasta Iivanaa, "kun lähti hän pois viivana". Kertoja tietää, että Iivanilla on oma maatuska Petrogradissa, mutta hän kaipaa silti Iivanin tuoksua ja yhteisiä hetkiä Kaisaniemen puistossa. Kaupunkien puistot olivat homomiesten kohtaamispaikkoina yleisiä jo 1900-luvun alussa, ja Kaisaniemen puisto pisoaareineen oli poliiseillekin tuttu "synninpesä" (Hagman 2016, 62-63, 197, 205). Iivanin muisto nostaa hymyn kertojan huulille:

Hei, juu, jupi jupi juu.

Näin naurussa suu

herttaista hetkeä muistelen viel,

kun kohtasin sun Kaisaniemen tiell,

siell ensi kerran niin

otit minut kiin.

Ristin löit rintaas ja kysyit: moshna, vot?

Heti silloin vaihtui suutelot.

Vot,

Haroshi flikushki,

näin lausui Iivani.

Sun harmaja takkisi,

lättänä lakkisi.

Syömmeni hurmasi, oi.

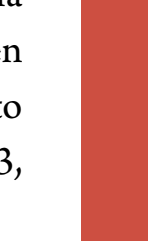


Laulussa on hyvin poikkeuksellisen voimakas kosketuksen ja kohtaamisen kuvaus. Harmaa takki ja lättänälakki luovat hyvin maskuliinista kuvastoa. Toisaalla laulussa haikaillaan Venäjän sotilaspojan hajua: "Vaan muisto ihanin on tuoksu Iivanin, vaikk' aika on vaihtunut, tuoksusi haihtunut, unhoita en sitä pois." Ei tuota minkäänlaisia ongelmia lukea tekstiä muiden katseilta salatuksi puistokohtaamiseksi, varsinkin kun se seuraavassa säkeistössä yltyy kiihkeäksi puistoseksin kuvaukseksi, jossa aistit ovat auki ja hetkestä otetaan kaikki irti.

Hei, juu, jupi jupi juu.

Suuta vasten suu

Kaisaniemen penkillä haaveiltihin,

vaikk sanoja ei ymmärretty siin.

Niin, mitäs turhista

olis puheista;

temput vaan kun tietää niin tuntea sen saa,

kuinka ryssä taitaa rakastaa.

Jaa, armas, hempeä;

hän oli lempeä.

Ne suutelot kuumat

sun lempesi huumat

koskaan ne unhoitu ei.

Laulun auvoinen loppu ja viimeinen, kuumasta huumasta ja rakastamisen tempuista kertova säkeistö puuttuu kokonaan Tatu Pekkarisen vuonna 1928 levyttämästä versiosta. Sen tilalla on säkeistö, jolla koko laulun sisältö palautetaan hetero-oletuksen alle siten, että sen sisällössä on mahdotonta enää lukea viitteitä miesten välisestä seksihuumasta. Suhteen "normaalius" pakotetaan esiin tekemällä Iivaniaan kaipaavasta Helsingin heilasta raskaana oleva "ryssän maatuska" joka itkee hyljättynä. Lähes rautalangasta väännetty pakkoheteroseksuaalisuus tukee aikansa yhteiskunnan oletettua "normaalia" ilman kiusallisia kyseenalaistuksia (vrt. Karkulehto 2011, 80-81).Valitettavasti se samalla myös latistaa laulun tunnelman puhtaaksi pilkkalauluksi.

Tatu Pekkarisen julkaisussa Valikoima humoristisia lauluja (1929) laulu löytyy nimellä "Helsingin heila ja Iivana", ja painetussa versiossa on peräjälkeen molempien levytysten loppusäkeistöt. Tatu Pekkarisen levyttämässä versiossa (1928) on poistettu toiseksi viimeinen säkeistö ja Theodor Weissmanin levyttämästä versiosta (1930) puuttuu painetun version viimeinen säkeistö. Näkökulmaero on merkittävä. Pekkarisen heteronormatiiviseksi pakotetussa versiossa korostuu Iivanin toiseus, "ryssyys", sillä raskauden paljastava ivallinen loppusäkeistö asemoi kuulijan lemmenparin yläpuolelle: Iivanin tuoksu ja lättänälakki ovatkin yhtäkkiä sympaattisen muiston sijaan pilkkaa. Weissmanin versiossa kertoja saa loppuun saakka pitää eroottisen muistonsa: "ne suutelot kuumat, sun lempesi huumat, koskaan ne unhoitu ei." Pekkarisen levyttämässä versiossa loppusäkeistössä ei ole kuumaa huumaa eikä unohtumatonta lempeä, ainoastaan ikävää ja katkeruutta:

Hei, juu, jupi jupi juu.

Taas itkussa suu.

Kun muistoista murhe yhä suurenee

ja surujeni taakka raskenee.

Se tuskaa ikävää

hiukan lievittää,

kun herran lahjan lohdutuksen saanen piankin,

tuon muiston parhaan: pienen Iivanin.

Niin ryssän maatushka

vois tulla minusta.

Oi livana armas

se hetki ol karvas

kun luotani läksit sä pois. 
Nykynäkökulmasta, queer-teorioiden kautta tarkasteltuna näiden kahden version vertailu on hyvin antoisaa myös siksi, että heteronormatiiviseksi pakotettu esitys päättyy tuomitsemaan puistosuhteen, mutta seksuaalisuudeltaa avoimeksi tai vihjaavan homoseksuaaliseksi kirjoitettu esitys hyväksyy puistosuhteen, jopa hekumoi sen muistelulla. Tarinat on rakennettu niin selkeästi erilaisiksi, että vastaanottajalle tarjotut positiot eivät voi olla sattumaa, vaan tekijöillä on täytynyt olla mielessä tarjota vapaamielisempiä tulkintamahdollisuuksia, olivatpa ne sitten hetero- tai homoseksuaalisia. Weissmanin levytys pyrkii mediaesityksenä rikkomaan Pekkarisen esityksen ennakko-odotusten mukaista, vanhakantaista, väkisin ylläpidettyä ja normalisoitua maailmankuvaa. (Karkulehto 2011, 42-43, vrt. myös Rossi 2005, 12-13.)

\section{Sörkän tuoksuvin "ruusu"}

"Sörkän ruusu" kuuluu nykyisin iskelmiemme ikivihreisiin, mutta harva tulee ajatelleeksi, että Annikki Tähti levytti paljon soitetun versionsa niinkin myöhään kuin vuonna 1978, ja Carolan kohtalokas versio tallentui levylle vasta vuonna 1983. "Sörkan ruusu" levytettiin kuitenkin ensimmäisen kerran jo 1930-luvun alussa. Koko laulu oli toisen maailmansodan jälkeen 1970-luvulle saakka enemmän tai vähemmän unohduksissa, eikä siitä ole noilta välivuosikymmeniltä yhtään levytystä.

"Sörkan ruusu" syntyi tyypillisen kupletin tavoin: tuttuun sävelmään kirjoitettiin uusi, pilkkasävyinen teksti (vrt. Hirviseppä 1969, 9). Sävelmänä toimi yksi vuoden 1929 suurimmista hiteistä, Evert Suonion säveltämä "Villiruusu". Ture Aran tunnetuksi tekemään lauluun Reino Palmroth kynäili nimimerkillä M. Turma uudet sanat, joissa irvailtiin Sörnäisten pahamaineisista salaviinakortteleista. Sörnäinen oli ollut jo 1900-luvun alusta saakka pahamainen kaupunginosa, jossa Sörkan sällitja sakilaiset huligaanit lietsoivat kauhua kaduilla ja kaikenlaiset laittomuudet, prostituutio ja raiskaukset pitivät poliisin työllistettynä (Koskela 2018, 28-30; 50-67).

"Sörkan ruusun" levyttivät ensimmäisinä Ilmari Sitari ja Amarillo-orkesteri vuonna 1932. Ilmari Sitarin nimimerkin taakse kätkeytyy näyttelijä ja oopperalaulaja Reino Volanen (Hirviseppä 1969, 157). Laulaja eläytyy lakonisesti ja liioittelematta Sörkän ilolinnun rooliin, puuteroi nokkansa ja antautuu gentlemannien piiritykselle. Levytyksestä puuttuu naisroolia imitoiva falsettilaulu, nasaalius ja kiherrys, joilla usein kupleteissa ilmennettiin sukupuolta (Henriksson 2014, 90).

Miss' päättyy Pitkäsilta ja alkaa Söörnäinen

kas siellä mä joka ilta joroissa jatsailen.

En milloinkaan mä yksin jää, mua "keltemannit" piirittää,

Mä olen Sörkan ruusu, oon kukka kallehin.

Miss' jauhaa jazzirumpu ja haitari se soi,

ruusuksi aukes' umpu, se mulle maineen toi.

Siks' tsalien kanssa karkeloin ja nokkani mä puuteroin,

kun oon mä Sörkan ruusu, oon kukka kaunehin.

Mä miksi surra huolisin, teen "varpusesta" flitsarin,

kun olen Sörkan ruusu, oon kukka tuoksuvin.

Kertojan toiseutta ilmennetään monin erilaisin sanankääntein. Hänen maineensa on syntynyt heti puberteetin myötä, kun hänen nuppunsa "aukesi ruusuksi". Hän liittyy aikakauden pahamaineiseen moderniin laitakaupunkiin, Sörnäisiin, ja siellä hän on kuin kotonaan paheellisen nuorisomusiikin äärellä, jatsirummun säestämissä joroissa, pirtutaskumatti "varpunen" kädessään. Koulutustaso on matala, mikä käy ilmi siitä, että sana gentlemanni ei osu ihan oikein hänen suussaan; karkeat slangi-ilmaisut ovat luontevampia. 
Laulajan äänenkäyttö ja sivistynyt ääntämys luovat aluksi mielikuvan vanhenevasta homomiehestä, joka puuteroi ikäänsä peittoon karkeloidessaan nuorten miesten ("tsalien") kanssa, juottaessaan ja viihdyttäessään näitä. Mutta tekstisisältö ei tue tuota tulkintaa: tekstistä käy ilmi, että tämä "ruusu" on hyvinkin haluttua seuraa. Poikaprostituutio ei ensimmäisenä tule mieleen, sillä laulajan ääni on kovin kypsä. Ehkä selkeimmin mieleen piirtyy Sörkän salakapakan tiskiltä kuva hemaisevasta ja itseironisesta, vahvasta transruususta, joka nauttii nuorten miesten seurasta ja ehkä tarpeen tullen myy palveluksiaan. Ilmari Sitarin vanhasta levytyksestä tosin puuttuu suoraan seksipalveluihin viittaava säkeistö, jonka sekä Annikki Tähti että Carola ovat myöhemmissä levytyksissään ottaneet mukaan: "Käy tänne, poika armas, käy Sörkan ruusun luo, on hänellä pehmyt parmas, hän sulonsa sulle suo." Lisäksi lauluvihkosessa Suosituimmat sävel- ja laulu-uutuudet (1932) lauluun on kirjattu säkeistö, josta käy ilmi ruususen eroottinen vetovoima: "Mua jentat kaikki siellä kateina katselee. Mutt tsaikkarit riemumiellä kiihkoissaan hihkaisee."

Sörkan oletettua transruusua voi tarkastella passing-käsitteen näkökulmasta: käykö Sörkän transruusu naisesta? Onko tarkoitus käydä? Homoseksuaalien syrjinnän historiassa seksuaalisesti ei-tavallisten on täytynyt yhteisön edessä käydä heterosta, ja transsukupuolisten henkilöiden "täytyy” käydä miehestä tai naisesta (Karkulehto 2011, 158-160). Minun mielikuvissani Sörnäisten 1930-luvun salakapakka on miljöö, jossa Sörkän transruusun olemisen oikeutta ei kyseenalaisteta: hänen kukkeutensa tunnistetaan ja tunnustetaan sellaisenaan. Samassa salakapakassa saattoi 1930-luvulla hyvin maleksia joutilaita työläisnuorukaisia, jotka hankkivat "helppoa rahaa" antautumalla vanhempien homomiesten suuseksin objektiksi (Hagman 2016, 95; 101).

\section{Paljastan isällesi että olet homppeli}

Toisen maailmansodan jälkeen suhde homoseksuaalisuuteen muuttui Suomessa. Skandaalilehdistö ja poliisi alkoivat tarkkailla epäilyttäviä miessuhteita, ja tuomiot samaa sukupuolta olevien haureudesta lisääntyivät huimasti. Muutoksen syyksi on arveltu sodan poikkeustiloissa nähtyjä tai koettuja homoseksuaalisia tekoja, jotka on myöhemmin yritetty kieltää ja torjua, sekä natsi-Saksasta levinnyttä tuomitsevaa asennetta. (Hagman 2016, 171-182; 208-210;219-220.) Sodan suoman poikkeustilan turvin monenlainen tavallisesta arjesta eroava käytös ja kokeilu oli sallitumpaa kuin aiemmin, ja homoseksuaaliset kokeilut ja suhteet tulivat tutuiksi niin rintamalla kuin suurimpien kaupunkien katukuvassakin (Mustola, 2006, 172-183). Sodan jälkeen seurasi poikkeustilasta irtautuminen, vapaamielisyyden tuomitseva moraalinen krapula ja normalisoiva jälleenrakentaminen, jolla seksuaalisen käyttäytymisen rajat neuvoteltiin uudelleen tiukan heteroseksuaalisiksi. Homoseksistä tehtiin jälleen yhtenäisyyttä uhkaavaa ja vieroksuttavaa, se nostettiin kirjoituksissa ja puheissa esiin puhtaasti heteroseksuaalisuuden binäärisenä vastakohtana ja vaarallisena ilmiönä. (Juvonen 2015, 157-158; 161-163; 173-177.) Myös iskelmäkuvaston sukupuolisuus tuntuu muuttuneen: yhä harvemmin mieslaulaja lauloi naiselle kirjoitetun tekstin ilman muutoksia. Havaintojeni mukaan laulujen "poika" muuttui entistä systemaattisemmin mieslaulajan suussa "tytöksi". Skandaalilehtien artikkelit olivat ilmeisesti pysyvästi horjuttaneen kuulijoiden automaattista hetero-oletusta, johon esiintyjät olivat aiemmin voineet luottaa. Homoseksuaalisuudesta oli tullut näkyvä vaihtoehto, johon kuulijoiden ajatusten ei toivottu harhautuvan.

Yksi 1950-luvun suurimmista hiteistä, "Suklaasydän”, päätettiin kuitenkin levyttää 23-vuotiaan Reijo Kallion laulamana tekstisuomennosta muuttamatta. Amerikkalainen kantrisävelmä "Mama’s Pearls" ei herättänyt kotimaassaan Margaret Whitingin levytyksenä suurempaa huomiota, mutta

$$
\text { 西 }
$$


Suomessa se nousi huippusuosituksi Brita Koivusen viattomana tulkintana: levystä myönnettiin suuren myynnin johdosta Suomen historian toinen kultalevy vuonna 1956 (Bagh \& Hakasalo 1986, 330). Suuren suosioon vaikutti varmasti myös svengaava sovitus, jonka katsotaan aloittaneen jazziskelmien aikakauden Suomessa (Poutiainen 2011,29, 45). Reijo Kallion levytys tehtiin samana vuonna, jäykemmällä sovituksella, mutta samalla viattomuudella. Kuitenkin niin moni asia oli toisin.

Kun nuoren miehen ujoimman

näin pöydässä pienen kahvilan,

niin syystä jota tiedä en

sain hältä suklaasydämen.

Suklaasydän, tinakuoret, aina murtuu sulaen.

Niitä tarjoo miehet nuoret, aitoja vain saa mä en.

Reijo Kallion herkässä tulkinnassa keskiöön nousee homosuhteiden solmimisen vaikeus. Nyt mies on katseen ja viettelyn kohteena tavalla, joka tuli hyväksytyksi kulttuurissamme vasta 1990-luvun mediaesityksissä, lähinnä tv-sarjoissa ja mainoksissa (Rossi 2003, 25; vrt. Karkulehto 2011, 165-170). Tässä laulutekstissä mieskertoja teeskentelee ymmärtämätöntä saadessaan toiselta mieheltä huomionosoituksen kahvilassa. Kertosäkeestä käy ilmi, että suklaasydämiä on tarjottu ennenkin, mutta "aitoja vain saa mä en”. Tällä nuorella herralla on ns. haku päällä, hän kaipaa vakiintunutta parisuhdetta eikä vain seikkailua. Seikkailuun hän kuitenkin antautuu, sillä mies "ulkona mua kuljettaa ja ostaa minkä irti saa". Kohtaamiseen tuntuu liittyvän salailun ja häpeän tunne, joka muun muassa queertutkija Eve Kosofsky Sedgwickin mukaan aktivoituu homokohtaamisen katseessa ja nähdyksi tulemisessa, kuten Harri Kalha $(2012,135)$ kirjoittaa. Kiihkoa saattaa olla, mutta aito kiintymys laulumme päähenkilöltä jää puuttumaan:
Hän silmiin kyllä katsoo mua

ja joskus saattaa innostua,

mutta jäljennös on arvoton

jos suklaata vain sydän on.

Laulun kertoja ottaa ohjat käsiinsä ja uhkaa paljastaa nuoren miehen seksuaalisen taipumuksen koko suvulle: "Suklaasydän sisällensä kätkee halvan sormuksen. Kerron hänen isällensä aitoja jos saa mä en." Näin iskelmäteksti onnistuu nostamaan esiin kaapissaolon ongelmallisuuden ja outing-käsitteen: kaappihomouden pakkojulkistaminen ilmenee laulussa jopa kiristyksen keinona.

Karkulehto (2011, 160-162) esittelee Sedgwickin teoriaa kaapin käsitteestä ei-tavallisen seksuaalisuuden kontekstissa. Kaappimetafora kuvaa yleisesti seksuaalisen toiseuden ja identiteetin aluetta, josta ei voi puhua ääneen, josta on vaiettava. Siksi kaapin käsitteeseen liittyy runsaasti kiertoilmauksia, salaisuuksia ja rajankäyntiä tietämisen ja ei-tietämisen välillä, julkisen ja kätketyn välillä. Sen vuoksi Brita Koivusen esittämässä versiossa naiivi uhkaus isälle kertomisesta jää hiukan lapselliseksi ja vaarattomaksi. Mutta miehen laulamana lause sähköistää koko säkeistön: tässä kiristetään kevytmielistä kaapissa olevaa suklaapoikaa, ja uhataan paljastaa hänen homoutensa koko suvulle, ja mikä pahinta: isälle. Tämä on konkreettinen uhkaus, kun otetaan huomioon, että homoseksuaalisuus oli kriminalisoitua ja sosiaalisesti tuomittua, ja juuri samoihin aikoihin skandaalilehdet julkaisivat aiheesta paljastuskirjoituksia. Samansukupuolinen seksisuhde johti tuolloin paljastuessaan oikeuteen, jossa 1950-luvun aikana jaettiin monikymmenkertainen määrä tuomioita aiempiin vuosikymmeniin nähden (Hagman 2016, 193, 207-208, 295). Lainsuojattoman asemansa vuoksi seksuaalivähemmistöt olivat alttiita kiristysyrityksille, ja monelle homoseksuaalisuuteen liittyikin jatkuva huoli ja pelko paljastumisesta, 
syrjinnästä ja sosiaalisesta leimautumisesta (Juvonen 2015, 224-228; Hagman 2016, 123-126).

\section{Teinipojat arabisheikin seksiorjina}

Viimeisenä iskelmällisenä mediaesityksenä käsittelen Lähi-idästälähtöisin olevaa tanssi-iskelmää "Mustapha", jonka "Suklaasydämen" tavoin Suomessa teki tunnetuksi Brita Koivunen, vuonna 1960. Paljon tuntemattomammaksi on jäänyt samasta laulusta samana vuonna tehty toinen levytys, jossa laulajina ovat Raittisen tuolloin teini-ikäiset veljekset Eero ja Jussi. Laulu sijoitettiin heidän esikoissinglensä"Banjo Boyn" B-puolelle. (Latva \& Tuunainen 2004, 354-356.)

Kun minareetit näen hopeaiset

ja kaikki näköalat arabialaiset,

niin yhä muistan sitä miten kerran

mä siellä tavata sain erämaiden herran.

Teinipojille vaarallinen erämaan sheikki on seikkailun synonyymi: "Mitä minä siitä silloin välitin, että hänen nimensä on pahamaineisin." Nopeasti pojat oppivat sheikiltä myös rakkauden kielen, joka tunnetusti yhdistää eri kulttuureista tulevia rakastavaisia: "Mä opin lauseen silloin ihanan: Ana bahebak, sua rakastan."

\section{Mä heti tunsin että ainiaan}

vain tahdoin olla hänen lempivaimonaan.

Mutta tapaan miesten itämaisten

hän hyvin rakkauden tunsi naisien.

Hän minut saattoi laivaan valkeaan, ja sillä viimein tulin kotisatamaan.
Ei ollut tarpeen lukko haaremin,

mä hälle ikuisesti kuulun kuitenkin.

Ryöstäjä hurmaa nuoret kertojat, ja he haluaisivat iäti olla sheikin lempivaimoina. "Itämaisten miesten tapaan" Mustapha kuitenkin tuntee myös naisten rakkauden, ja hän hankkiutuu poikarakastajista eroon, palauttaa nämä kotisatamaan. Mustaphasta tehdään eroottinen objekti, röyhkeäkäytöksinen erämaan macho, mutta ilmeisen lyömätön rakastaja, koska vielä palautettunakin pojat sanovat kuuluvansa "hälle ikuisesti".

Orientalistisissa iskelmissä on usein kuultu haaremiin suljetun neidon kaipaavaa ääntä. Ehkäpä Eeron ja Jussin laulu antaa äänen nuorille tanssipojille, köçekeille, joita sheikkien ja sulttaanien palatseissa myös asui, esiintyi ja toimi seksityöläisinä. Köçekit olivat kuvankauniita pitkätukkaisia nuorukaisia, jotka tanssivat kahviloissa ja hoveissa, häissä ja uskonnollisissa juhlissa. Tanssipoikaperinne oli yleinen kaikkialla Lähi-idässä ja Pohjois-Afrikassa, mutta Ottomaanien valtakunnassa se oli erityisen suosittu. Tanssit olivat naismaisen pehmeitä ja seksuaalisia, ja niiden homoeroottiset kuvaelmat hämmensivät länsimaisia matkaajia, kunnes julkiset köçek-esitykset kiellettiin 1800-luvun puolivälissä. Kieltoa ei kuitenkaan valvottu ja tanssipoikien työ jatkui myös palatseissa, joissa pojat tarjosivat eroottisia iloja niin sulttaaneille kuin muillekin palatsien miesasukkaille. (Boone 2014, 102-107; Erdoğan 2000, 73-77.) Toisaalta laulussa kaikuu eksoottisen muukalaisseksin polte, jollainen sävyttää myös "Hampurin heilaa" ja "Iivanan jenkkaa". Etnisesti, kulttuurisesti ja kielellisesti toinen - saksalainen, venäläinen tai arabi - koetaan outoudessaan houkuttavaksi ja kiihottavaksi, stereotyyppiseksi objektiksi, kielletyksi hedelmäksi. (vrt. Rossi 2003, 187-198)

Se, että Eero ja Jussi Raittinen olivat laulun levytysaikoihin 16- ja 17-vuotiaat, antaa esitykselle lisää pervokerrointa. Poikien lakoninen laulutyyli

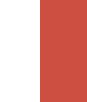


ja ilmeisen tahaton eroottisuus nostaa tuohtumuksen sijaan kuulijan huulille hymyn: tämä on parasta camp-iskelmää. Susan Sontagin (2017, 386-387; 391-392) kuuluisassa esseessä camp määritellään siten, että sen olemukseen kuuluu rakkaus keinotekoiseen ja liioiteltuun; sen ytimessä on viattomuus, joka turmeltuu kuin vahingossa. Teinipoikien esittämässä "Mustaphassa" on monotonista vakavuutta, joka on campin edellyttämällä tavalla ristiriidassa tarinan uskomattomien käänteiden ja tunnetta huokuvien ilmausten kanssa. Camp-asenne auttaa nauramaan myös lauluun ujuttautuneelle pedofilian peikolle, sillä kuten Sontag $(2017,399)$ huomauttaa, camp ei ole ilkeilyä, vaan tietyllä tavalla se on keino "neutraloida moraalinen närkästys" pois leikillisyyden avulla.

\section{Toisin luettua elämää}

Käsittelemäni sotaa edeltävät iskelmätekstit kuulostavat näitä myöhempiä lauluja vähemmän keinotekoisilta miehen suussa - ainakin omasta mielestäni -, ja siksi ne tuntuvat raikkailta ja ilahduttavilta ilman camp-katseen siunaustakin. Ehkä niissä esitetty maailma on avoimempi ja jollain tapaa rehellisempi: niissä ei ole pakonomaista heteronormatiivista käännettä tai peittelyn halua, vaan Hampurin heilasta, lättänälakkisesta Iivanasta tai Sörkan transruususta lauletaan suoraan ja ylpeästi, ja niissä soiva kaipuu on pikemminkin koskettavaa kuin koomista.

Molemmat käsittelemäni sotienjälkeiset esitykset, Reijo Kallion ”Suklaasydän" ja Eeron ja Jussin "Mustapha", palauttavat kerronnan heteronormatiiviseen yhteiskuntaan. "Suklaasydämen" kertoja pysyy uhittelusta huolimatta kaapissa, isälle ei kerrota, eikä aitoa homorakkautta tavoiteta. Mustapha palaa naisen syliin ja palauttaa käytetyt teinipojat kotiin. Molemmissa lauluissa näkyy paitsi edellä mainitsemani sodan jälkeinen heteroseksuaalisuuden normalisoiva jälleenrakennus, myös piirre, josta Karkulehto $(2011,152-156)$ käyttää nimitystä heteronostalgia: on kuin koko homotarina olisi kerrottu vallitsevien heteronormien pönkittämiseksi, kuin varoittavana esimerkkinä liiallisesta vapaamielisyydestä. Ehkä juuri tämä heteronostalgisuus aiheuttaa sen, että molempia esityksiä tekee mieli tarkastella hymynkare huulilla camp-kontekstissa. Molemmista voi toki nauttia ilman camp-näkökulmaakin, mutta campin tarjoama humoristinen kulma tekee esityksistä varmasti moniulotteisempia ja yllättävämpiä.

Laulujen maailman tutkiminen queer-teorioitten kautta on selvästi muuttanut omaa suhdettani niiden sisältöihin ja esityksiin. Kun pari vuosikymmentä sitten tutustuin ensi kerran näihin esityksiin, kaikkien niiden viehätys ja viihdearvo liittyi minulla lähes puhtaasti camp-aspektiin ja tahattoman komiikan hoksaamiseen. Nyt tulkitsen niitä paljon avarammin, kurkistusluukkuina toisenlaiseen todellisuuteen, joka olisi voinut olla - ja nykyisin on - aivan yhtä totta kuin hetero-oletukseen perustuva todellisuus. Vanhojen iskelmätekstien heteronormatiivisuuteen peilattuna näissä esityksissä kaikuisi päällimmäisenä vain höpsö koomisuus. Toisin luettuina ne ovatkin täynnä samastuttavia kokemuksia, kipupisteitä ja kiellettyjä onnentunteita: elämää.

\section{Lähteet}

\section{Kirjallisuus}

Bagh, Peter von \& Hakasalo, Ilpo. 1986. Iskelmän kultainen kirja. Helsinki: Otava.

Boone, Joseph Allen. 2014. The Homoerotics of Orientalism. New York: Columbia University Press.

Erdoğan, Sema Nilgün. 2000. Sexual life in Ottoman society. Istanbul: Dönence. Gronow, Pekka \& Saunio, Ilpo. 1990. Ä̈̈nilevyn historia. Porvoo; Helsinki, Juva: WSOY. 
Fetterley, Judith. 1978. The Resisting Reader: A Feminist Approach to American Fiction. Bloomington: Indiana University Press.

Hagman, Sandra. 2016. Seitsemän kummaa veljestä. Kertomuksia suomalaisen homoseksuaalisuuden historiasta. Helsinki: Gaudeamus.

Hall, Stuart. 1999. Identiteetti. Suom. Juha Herkman \& Mikko Lehtonen. Tampere: Vastapaino.

Hekanaho, Pia Livia. 2010. "Queer-teorian kummia vaiheita", 144-160. Teoksessa Käsikirja sukupuoleen. Toim. Saresma, Tuija, Rossi, LeenaMaija \& Juvonen, Tuula. Tampere: Vastapaino.

Henriksson, Laura. 2014. Laulettu huumori ja kritiikki J. Alfred Tannerin, Matti Jurvan, Reino Helismaan, Juha Vainion ja Veikko Lavin kuplettiäänitteillä. Helsinki: Suomen musiikkitieteellinen seura.

Hirviseppä, Reino. 1969. Hupilaulun taitajia Pasi Jääskeläisestä Juha Wat Vainioon. Porvoo; Helsinki: WSOY.

Juvonen, Tuula. 2015. Varjoelämää ja julkisia salaisuuksia. Tampere: Vastapaino.

Kalha, Harri. 2012. Tom of Finland - Taidetta seksin vuoksi. Helsinki: SKS.

Karkulehto, Sanna. 2011. Seksin mediamarkkinat. Helsinki: Gaudeamus.

Koskela, Kari. 2018. Huligaanit. Katuelämää Sörkassa suurlakosta sisällissotaan. Helsinki: SKS.

Kukkonen, Einari. 1980. Isoisän gramofooni. Suomalaisen levyiskelmän vaiheita 1929-1939. Jyväskylä: Kustannuskolmio.

Latva, Tony \& Tuunainen, Petri. 2004. Iskelmän tähtitaivas - 500 suomalaista viihdetaiteilijaa. Jyväskylä: WSOY.

Löfström, Jan. 1999. Sukupuoliero agraarikulttuurissa: "se nyt vaan on semmonen”. Helsinki: SKS.

Löfström, Jan. 2015. "Miten päätellä, onko hiljaisuus vaikenemista? 'Homoseksuaalisuus' agraarikulttuurin perinneaineistoissa', 121-135. Teoksessa Salattu, hävetty, vaiettu. Miten tutkia piilossa olevia ilmiöitä. Toim. Häkkinen, Antti \& Salasuo, Mikko. Tampere: Vastapaino.

Mustola, Kati. 2006. "Homoseksuaalisuus ja sota: Kahden veteraanin tarinat", 171-189. Teoksessa Ihminen sodassa: Suomalaisten kokemuksia talvija jatkosodasta. Toim. Kinnunen, Tiina \& Kivimäki, Ville. Helsinki, Jyväskylä: Minerva.

Poutiainen, Ari. 2011. "Sopuisasti ja sulavasti svengaten. Jazziskelmää määrittävät elementit", 19-50. Teoksessa Suklaasydän, tinakuoret Jazziskelmä Suomessa 1956-1963. Toim. Poutiainen, Ari \& Kukkonen, Risto. Helsinki: Musiikkiarkisto JAPA.
Rossi, Leena-Maija. 2003. Heterotehdas. Televisiomainonta sukupuolituotantona. Helsinki: Gaudeamus.

Sedgwick, Eve Kosofsky. 1990. Epistemology of the Closet. Berkeley, Los Angeles: University of California Press.

Sonntag, Susan. 2017 [1964]. "Huomautuksia campista" (Alkuteos "Notes on Camp"), 386-400. Suom. Jyri Vuorinen. Teoksessa Estetiikan klassikot II. Modernista postmoderniin. Toim. Ilona Reiners, Anita Seppä \& Jyri Vuorinen. Helsinki: Gaudeamus.

\section{Laulujen sanat}

Larin-Kyösti. 1897. Tän pojan kevätrallatuksia. Helsinki: Otava.

Pekkarinen, Tatu. 1929. Valikoima humoristisia lauluja. Helsinki: Merkur

Suosituimmat sävel-ja laulu-uutuudet. Amarillo-vihko 4. 1932. Helsinki: Orkesteri Amarillo.

Vuoristo, Aapeli (toim.). 1988. Suuri Toivelaulukirja 7. Helsinki: Musiikki Fazer.

\section{Äänitteet}

Aittalaulu. Säv. Emil Kauppi, san. Larin-Kyösti. Gramophone 2-282014 / 2-282015. Iivari Kainulainen 1912

Hampurin heila. Säv., san. trad. Gramophone 2-282014 / 2-282015. Iivari Kainulainen 1912.

Iivanan jenkka. Säv. trad., san. Tatu Pekkarinen. Homocord O.4-23087. Theodor Weissman \& Homocord-orkesteri 1930

Sörkän ruusu. Säv. Toivo Palmroth, san. Reino Palmroth. Odeon A228224. Ilmari Sitari \& Amarillo-orkesteri 1932.

Suklaasydän (Mama’s Pearls). Säv. G. Clarkson, H. Clarkson, D. Siegmann, suom. san. Saukki. Melody M309. Reijo Kallio 1956.

Mustapha (Mustapha). Säv. Bob Azzam, suom. san. Kari Tuomisaari. Decca 45SD5507. Eero ja Jussi 1960.

\section{Äänitetiedot}

Haapanen, Urpo (1990) Suomalaisten äänilevyjen taiteilijahakemisto 1901-1982. Suomen äänitearkiston julkaisu N:o 23. Helsinki: Suomen äänitearkisto.

Yle Arkiston ja kirjastojen äänitetietokanta Fono. http://www.fono.fi (16.1.2021).

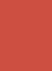


Suomen kansallisdiskografia Viola. https://www.kansalliskirjasto.fi/fi/palvelut/ kansallisbibliografiapalvelut/viola-suomen-kansallisdiskografia (16.1.2021).

Suomen äänitearkiston ja Musiikkiarkiston tietokanta Fenno. https://fenno. musiikkiarkisto.fi/ (16.1.2021).

\section{Soittolista}

Aittalaulua lukuun ottamatta laulut on kuunneltavissa kokoamaltani julkiselta You Tube -soittolistalta Kerron hänen isällensä. https://www.youtube. com/playlist?list=PLOHRCQnv92Ep3-EavlvOJO1jo0ZJapSoe 